\title{
Localizing the Korean Variety Shows in China Review of the Differences Between Policy, Market and Culture
}

\author{
Chenxuan $\mathrm{Gao}^{1, \uparrow, \mathrm{a}, *}$, Anqi $\mathrm{Wu}^{2, \dagger, \mathrm{b}, *}$, Qingyuan Yang ${ }^{3, \dagger, \mathrm{c}, *}$
}

\author{
${ }^{1}$ Faculty of Arts,Monash University,Melbourne,Australia ,3000, \\ ${ }^{2}$ School of Literature \& Communication, Xinlian College of Henan Normal University, Zhengzhou, 450018, China, \\ ${ }^{3}$ Stan Richards School of Advertising and public relations, Moody College of Communication,The University of Texas \\ at Austin,Austin, 78712,America , \\ *Corresponding author email. ${ }^{a}$ cgao0014@student.monash.edu, ${ }^{b}$ wu13939253163@163.com, ${ }^{c}$ qyy1120@utexas.edu \\ These authors contributed equally.
}

\begin{abstract}
This article aims to find out how the differences of policy, market and culture between Korean and Chinese influence the process of Chinese localization and the development of Chinese television industry. The collection of literature summaries from journals and news, the research methods of the literature review are used to discover that much literature in social science focus on how the television programs introduced from Korea influence Chinese people, but lack the summary articles about specific analyzing the differences of Korea and China. The results of this article are as followed: Firstly, under the guidance of policies, the TV industries of China and South Korea aim to get rid of the shackles of cultural imperialism. After transplanting foreign TV programs to develop their TV industries, they are now carrying out the localised development of the TV industry. Secondly, different progresses of development in television industry lead to two distinctive market structures. Korea focuses on entertainment shows and aims to spread out to Asian market. Chinese market lacks diversification, and the television industry is stably developed by directly purchasing Korean programs for localization. Finally, cultural differences about food and etiquette have some obstacles to Chinese localization, while these differences helps Chinese television stations to increase awareness of promoting creativity and self-made programs. This article analyzes the influence of Korean programs on the development of China's television industry. Under the guidance of policies, the Chinese television industry combines its market development and cultural advantages to carry out original localized programs.
\end{abstract}

Keywords: Korean variety shows, Chinese localization, cultural policy, market, cultural differences

\section{INTRODUCTION}

As globalization speeds up in modern times, information communication and cross-culture activity become normal and more frequent. New forms of media created by progressing technology have provided more methods to disseminate information and culture to the audience in television industry. The international broadcasting and other media services was produced and influenced by the global communication technologies such as cable, satellite, and the Internet [1]. Reality TV, one of the media forms promoted by technology of the internet, is an innovative genre and tool for encounter of different cultures through cultural flows. It refers to a television programming which documents un-scripted real-life situations, which became popular in the 1990s and 2000s.

However, reality show was not well-developed in China since Chinese audience has not had the opportunity to watch the reality show since 1990s. Due to the short investment of reality shows, the quantity of Chinese reality shows is limited and the quality of them is not good as well, which only includes several shows such as Happy Camp, so innovation is necessary in Chinese TV shows. Compared to the lack of reality shows, Chinese own a huge population of the audience. In 1987, there was about 116 million television users in China and it kept increasing to 1.188 billion in 2005 [2]. Besides, entertainment shows have been ranked as one 
of top four genres of Chinese television [2]. China, as a huge and potential market for foreign countries, attracts their attention. It is regarded as one direction to acquire more audience and profits, which contributes to the development of the entertainment industry to be worldwide. Fortunately, since China joined WTO in 2001, the Chinese domestic market was open, and a large number of foreign media organizations rushed in. At the same time, it offers China chances to introduce various forms of TV shows.

Whereas, Korean television industry is reverse. There are more and more innovative and delicate productions created by Korean television industry, such as diverse TV shows, dramas and idol-derived programs, but their domestic market is insufficient, due to the limitation of Korean population. Therefore, it is significant for them to get more markets. In 1997, Korea experienced a huge Asian currency crisis. In order to recover from the decreased economic, Korean government changed their policy, which is facilitating the exportation of Korean cultural products to entire Asian market. They aimed to spread media as a cultural industry. And then in 2002 the invention of satellite broadcasting contributes to the dissemination of programs. By early 2006, Korean cultural productions including television drama, film, pop music, etc., had become popular among audience in Asia [3]

While Korean TV shows started broadening their influence and acquire more audience in Asian even Chinese market, the Chinese entertainment industry also needs new blood to activate. The presence of Korean shows solves the problem. Many producers bought their copyright and made programs as Chinese versions. And Nowadays, the introduction of entertainment shows continues such as purchase of the format of top singing reality show of MBC, I am a singer. Due to the status quo of continuous introduction, it is significant for us to understand how to better localize Korean reality shows in China.

This study will explore and research three factors involved in the process of localization of reality shows from Korea to China. The first is regulations of two governments. Some contents in Korean shows are allowed might not be able to broadcast in China according to distinctive policies, which is necessary to consider. Besides, when targeting distinctive nations, it is necessary to analyze the structure of markets from two countries and what these markets want from the productions. According to the difference, the topic and the contents of the show should be localized. At last, cultural differences need to be taken into consideration. Even though Korean culture and Chinese culture are all eastern cultures, they still contain different urban cultures and traditional customs. When promoting the Chinese version, cultural difference has to be localized. How markets, cultural differences and regulations influence the process of localization from Korean shows to Chinese versions is what this paper will illustrate in the following article.

\section{THE CULTURAL POLICY OF THE TELEVISION INDUSTRY}

\subsection{The policy of the television industry in Korea}

This part attempts to show that the influence of Korean cultural policy orientation on the Korean media industry. In the current world where media is highly liberalised, the product output of the media industry is not only the circulation of cultural symbols, but the copyright application of operating modes and cultural models is more representative. South Korean television industry and film industry have played a role as a vane for East Asia and even the world's media industry, which is the guiding role of Hallyu in East Asian media industry.

Notably, President Kim Dae Jung, who called himself President of Culture in 1998, set up the Basic Law on the Promotion of Cultural Industries in 1999 with a total budget of $\$ 148.5$ million for this project [4]. This policy enabled the Korean cultural industry to get rid of the oligopoly of the American media industry in the Korean media market. In the 1990s, the export of American cultural products occupied most of the Korean market, which to a certain extent restrained the local cultural industry development in Korea. This is undoubtedly true in the case of the opening up of Hollywood filmmakers' markets affected the life of the general local film industry. From 121 in 1991 to 63 in 1994 the number of movies produced each year fell. In 1994, Hollywoods local market share reached $80 \%$, compared to $53 \%$ in 1987 [4]. Under controlling the American market share in South Korea, South Korean cultural industry has ushered in a liberalised development. Regarding music and television industry models and self-creation, its systematic program creation form is used as a cultural assemble to carry out cultural products. The output of the product will transform the artistic value of the product into economic value in a more direct way. For instance, the reality shows such as Running Man are spread in cooperation between China and South Korea. On the one hand, South Korea conveys production knowledge and details to China in the form of a format bible. It uses the branding effect of Korean programs to attract the attention of Korean fans and overseas Chinese. On the one hand, China has introduced local tastes and culture through localised changes such as subtitles and advertisements, increasing the cultural belonging of Chinese descent and building a bridge of cultural exchange across the interaction [5]. 


\subsection{The policy of the television industry in China}

The TV industry in China started later than in Europe, the United States and even South Korea. After the Reform and Opening Policy in 1978, the television industry gradually began to develop. The Korean Wave culture profoundly influences the development of Chinese television industry. The cultures of the two countries are similar, and both countries are deeply influenced by Confucian culture. The content of the program is more restrained than the large-scale open scales in Europe and America.

However, Chinese macro-coordination and centralised control prevent Chinese television industry from being dominated by foreign capital in the Korean cultural industry market in the 1990s. Under Chinese national conditions, the priority of all mass media is to ensure that socialism with Chinese characteristics is promoted. On this basis, the Chinese television industry will be profit-oriented to spread. Therefore, Chinese television industry will restrict control over content such as violence, sex, and gambling, which has created a contradiction between the market growth of the television industry and content control policies. As a result, television marketing is by no means equivalent to content liberalisation. Chinese authorities are dedicating substantial resources to keeping stability in China. The state maintains tight control over potential dissatisfaction factors in the daily life, including neighbourhood watches, routine bag scans on the underground and the installation of China Central Television (CCTV) systems in every public place. The removal of unfavourable content from the TV program is only one (although important) element of this system [6]. Therefore, in 2018, the Implementation Rules on Further Strengthening the Management of Radio, Television and Online Audiovisual Arts Programs issued by the Beijing Municipal Administration of Radio, Film and Television stated that original audiovisual programs must be broadcast and filed as required to ensure that the the orientation, subject matter, content and scale in the programs need to be in a same standard.

\section{IMPORTANCE OF MARKETS}

Any commercial movement is indispensable from markets, no exception to the localization of Korean reality shows in China. Analyzing markets structure can contribute to understand target audience, demand of audience and the development of productions. Comprehension of Korean market leads us to the reason why it creates so many entertainment programs and why it has such as huge impact on Asian market as Korean wave. Whereas, digging into Chinese market helps us know why there is necessity to introduce Korean shows and how people could localize them to cater to Chinese market.

\subsection{What Korean market structure is and how it influenced Korean entertainment shows}

Korean market has always emphasized on the television industry as one of their development methods of economics and culture since Korea experienced the huge Asian currency crisis. Before Korea opened up their own way of Korean wave, the Korean market was full of American films and TV programs from Hollywood. Within the time, Korean market can only negatively receive such culture imperialism. However, as Korea liberates their market from western countries, it cultivated its own market according to their own target audiences. Under the ancient Korean culture, which is slowly decreasing though, women should stay at home to babysit children, do all chores and avoid showing up in front of other people, so they also spend most of their spare time at home, which TV is the most popular and frequent tool for enjoying. They became the main audience of the TV market, and their preferences became the marketing orientation of the industry, which became Korean soap operas, TV shows such as variety shows and so on. The domestic Korean market was largely affected and changed. Hollywood films occupied only $15.9 \%$ of the market in 1993, which decreased from $34.2 \%$ in 1985 before the liberation [7]. After activating its domestic market with its own Korean productions, it started to communicate these productions to entire Asian market. It began in the mid-1990s and extended to the 2000s, with huge exportation of Korean television serials and films to Asian countries such as China and Japan [8]. The influential and popular Korean productions led the Korean wave, which refers to a transnational movement.

\subsection{The status quo of Chinese Market and its effect on localization of Korean reality shows}

Chinese market is opposite to the Korean market which used to import lots of foreign programs, especially from American market. In official Chinese outlets audience can hardly foreign productions since the majority of them is not provided. Chinese audience can only watch foreign television programs on internet, which they need to spend much time find the sources of episodes and not to mention the programs with full Chinese subtitles. The insufficiency did not only happen to foreign productions, it also restricted Chinese shows. Because of the inadequate techniques and experiences of production creation, Chinese television market contain little entertainment programs, not to mention reality shows. However, as the life quality increases during modern time, people are more eager to pursue the cultural transnational activity, such as watching TV shows. Under the huge demand of TV shows in Chinese 
market, the incompatibility of lack of shows needs to be tackled. It is inevitable to encounter the problems and thwarts when developing an industry, so it is the same if developing the Chinese reality shows industry [9]. In order to make progress in the industry, introducing foreign reality shows and adapting them to local market is the most stable way [9].

During the localization process, the most important step is to adapt foreign programs to cater the audience, which is also one of the most significant aim of Chinese market. Under the current situation of Chinese reality show market, the target audience mostly concentrate on younger people from teenagers to about 35. They are easily attracted by good-looking appearance and famous celebrities. A famous reality show introduced from Korea called Dad Where Are We Going? is an excellent example. In order to attract Chinese audiences according to the market demand, it made some changes to make the fourth season more interesting. The directors of Dad Where Are We Going? decided to add the intern dad into the new season. These intern dad are all good-looking and fresh, which aims to target the teenage girls. One of them is Deng Lun, who is an actor and have been the main male character of several romantic dramas. Market, as a driving element for popularity, is indispensable to consider for the process of localization.

\section{THE CULTURAL DIFFERENCES BETWEEN CHINA AND KOREA}

Throughout the history of world civilization, the world was divided up into five culture spheres due to the geographic location. Korea and China are located in East Asia and are part of East Asia culture sphere. Thus, there are some similarities between two countries in culture such as traditional culture and traditional customs. However, there are some cultural differences between Korean and Chinese that need to be analyzed, including food culture and etiquette culture.

\subsection{Food Culture}

Food culture is not only one of the important cultures but also a necessary element of the cultural development of whole countries. In addition, food culture is mainly related to the production and life of human beings. Specifically, food culture is the sum total of human food production and the procedure of human diet. China and Korea are typical agricultural countries in East Asia but have their own food culture based on the long and abundant history.

\subsubsection{Korean food culture}

As for Korean food culture, Korean traditional food made by Korean which is more from nature due to their basic industry , and Korean think their dishes included an element named nature is health [10]. Although Korea is a developed country and focuses on developing its manufacturing industry and service industry, the agriculture industry is the main industry all the time. Therefore, rice is the staple food in the Korean diet, and then there are many cuisines about the rice which are found in Korean plate. For example, mixed rice with Kimchi is a representative dish that contains much of Kimchi and rice. In Korea, people prefer to make food with fermenting, boiling, seasoning, and pickling not to fry and bake food. The most popular one among these methods is fermentation, which can preserve foods and enrich their flavors [11]. This is the reason why Korean prefer to make and eat Kimchi, because it represents health.

\subsubsection{Chinese food culture}

Compared to Korean food, Chinese food is also more from nature, and Chinese food culture is consistently inherited and developed since the primitive society [12]. The inheritance of Chinese food culture is not interrupted due to the change of dynasty and social system [12]. Confucius long ago said, the desire for food and sex is part of human nature [12]. For Chinese people, they always believe that hunger breeds discontentment. Thus, the degree of attention about food for Chinese people is beyond what westerners can know, and Chinese people are good at developing recipes which include many incredible dishes as long as they have enough raw material. Thus, many westerners think that all food can be made and ate for Chinese people [12]. In China, people mainly depend on their living environment to make different dishes, which forms eight cuisines, including Sichuan Cuisine, Confucian Cuisine, Cantonese Cuisine, Jiangsu Cuisine, Zhejiang Cuisine, Fujian Cuisine, Hunan Cuisine and Hui Cuisine. Thus, Chinese people tend to focus on the flavour of dishes not a unified norm [12].

\subsection{Etiquette Culture}

Etiquette is a behavior pattern that can identify the relationship among people or people and things. Besides, etiquette conveys certain emotions such as trust, respect, congratulation and other feelings. The earliest etiquette is sacrificial rites which shows human deep reverence for nature. However, etiquette becomes a crucial part of social intercourse as the era consistently changes and develops. As an important part of traditional culture, etiquette culture exists in world civilization and has a great effect on human social activities. Korea and China are East Asia countries and are influenced by Confucian etiquette culture,but they have some differences in etiquette,especially about business etiquette. 


\subsubsection{Korean etiquette culture}

The main ideology of Korean culture is related to Confucianism since Confucianism was introduced to South Korea [13]. In addition, Korean life was relevant to Confucianism from then. For example, the personal life and commercial world of people to some extent [14]. In short, Confucianism has a high status and has a great effect on Korean society [14]. Furthermore, the etiquette of Confucianism plays an important role in Korean etiquette culture.

In South Korean, there are two crucial social etiquette in Korean business etiquette which are greeting and gift-giving. To show respect to another person, Korean businessmen need to bow to others with a handshake when greeting others. Besides, they tend to put their left hand under right forearm when shaking hands [14]. Keeping eye contact is very important and respectable during greeting [14]. It follows that good greeting is significant. In terms of gift-giving, businessmen do not think that gift-giving can form the unhealthy practices such as bribery and corruption. This is only a communication way which helps people to maintain the business relationship [14]. Thus, this etiquette plays an important role in Korean business communication.

\subsubsection{Chinese etiquette culture}

China is the birthplace of Confucian culture, and there is a specific definition of Chinese traditional etiquette that is a collective name about Chinese broad masses of traditional society who abode by etiquette model, etiquette system, etiquette code and other material and spirit culture that are related to etiquette before the May Fourth Movement [15]. In terms of the status of Chinese etiquette culture, it is one of the cores of Chinese traditional etiquette culture [15]. Compared to Korean etiquette culture, Chinese etiquette culture also focus on greeting and gift giving but differ from Korean.

As for Chinese greeting, Chinese businessmen tend to slight bow or nod and sometimes shake hands with other people when greeting to others. In China, shaking hands is a typical greeting way for Chinese, and people only reach out their right hand. For gift giving etiquette, scholars argue that it is a humiliating thing for Chinese people if they are accused of greed [16]. In China, giving expensive gifts is not appropriate and sometimes is regarded as bribery; on the contrary, presenting some small but wise gifts can greatly show the sincerity [17].

The cultural differences between China and Korea have great effects on the Chinese television industry. Although Korean television programs are introduced to China consistently in recent years, many Chinese television producers find that they copy the variety shows from Korean and represent them to the Chinese audience directly, audience cannot understand the meaning of these shows due to the cultural differences, which leads to the ratings dropped and causes some cultural conflicts [18]. Thus, in recent years, to cater to the Chinese audience and consider the cultural differences, Chinese television producers begin to readjust the content of variety shows introduced from Korean, including language, traditional culture, and other differences. This measure promotes the development of the Chinese television industry, helps Chinese television stations to recruit more new talent, and accelerates the procedure of localization to some extent.

\section{CONCLUSION}

The development of Chinese television industry is based on the original format cloning model, and creative innovation has been carried out to integrate its own audience needs and cultural characteristics. The development of Chinese television industry still has a development model of transplanting successful foreign television programs for adaptation. At the same time, China' $\mathrm{s}$ television programs have begun to be based on their cultural advantages. In the program innovation stage, programs such as Chinese Bridge and National Treasure are typical products. However, under the influence of cultural globalization and cultural imperialism, localized development based on foreign programs has become the normal operating mode of the development of the television industry.

To show a nuanced analysis on the influences of cultural differences on localizing Korean variety shows, the paper is divided into three of cultural policy, market and culture difference. Firstly, Comparing the policy orientation of China and South Korea, after solving the market monopoly of American cultural products, South Korea has given priority to the dissemination of domestic original cultural industries and actively promoted cultural dissemination. At least, it has served as a vane for the entertainment industry in East Asia. The role of Korean cultural products as a branding effect affects the development of the TV industry. While China is gradually narrowing the gap with the world' $\mathrm{s}$ leading TV industry countries, China' s official support and dissemination make it easy to push TV programs and attract the attention of audiences, even if the control of sensitive content makes the development of TV programs have certain limitations, it does not affect the basic needs and viewing experience of the viewers. Secondly, the Korean market has been dominated by western productions, especially Hollywood movies and programs. After the liberation from the American market, it pursued to create its displays to represent their culture and social environment, to service the audience. Because the primary target audience in the Korean 
market is housewives at home in the past, the initial generation of Korean productions focused on soap operas and romantic films. Along with Korean production development, the Korean market is insufficient for the supply, so they started to occupy other Asian markets. In contrast, the Chinese market has lacked foreign shows for a long time. And the Chinese television industry does not have enough ability to satisfy the Chinese market with their productions. To develop the Chinese TV industry and fulfill the demand of the Chinese market, Korean television shows are imported and localised. Because the good-look image is favourable by the Chinese target audience, Korean introduced performances are improved to cater to the Chinese market, such as Dad Where Are We Going?. Finally, it has been found that Confucian culture influences Korean culture and Chinese culture and reflects in the daily life of Korean people and Chinese people. While, the Korean culture is significantly influenced by Confucianism. As for the food culture, people in two countries choose food from nature; for etiquette culture, they pay more attention to greeting and gift-giving. Thus, when Korean programs are introduced to China, Chinese people watch and understand some contents directly without translation. However, there are some differences between the two countries. Korean people prefer to make healthy dishes using a fermentation method, but Chinese people focus on the taste of words, and all things can be food. In terms of etiquette, greeting Korean people and Chinese people is different, and they do not have the same attitude to giftgiving.

Entertainment program formats have now spread virus-like throughout the Chinese television industry. The television executives are on the lookout for the next form. This may well be the new Chinese Shangri-la television show, which began broadcasting in July 2001. This wilderness tour is being made in Beijing by the Weihan culture and the media company, unashamedly borrowed from successful formats from the overseas survivors. It includes three teams of six with ten days supplies of matches and food to a 30-day trek through the edges of the Himalayas. At present, $110 \mathrm{TV}$ stations broadcast Shangri-la. In addition to broadcasting, the participants' progress is covered on the web and in domestic journals. Shangri-la may be just the new dawn of television viewers in China, recalling the historical tradition of the Long March and the liberation of Tibet. Thus, the development of Chinese television industry still needs a long-term sustainable development process. Today, in the world of cultural globalisation, cultural copyright, market demand, and policy orientation are still important factors for the development of the television industry.

\section{REFERENCES}

[1] T. Flew, Entertainment media, cultural power, and post-globalization: The case of china' s international media expansion and the discourse of soft power. Global Media and China, 2016, 1(4), pp. 278-294. doi:10.1177/2059436416662037.

[2] Y. He, A. S. Tedesco, L, Timmins, Foreign introduced reality television in China's market. In Foreign Introduced Reality Television in Chinese Market, 2013, pp. 24. Philadelphia, PA Drexel University.

[3] C. Huat, K. Iwabuchi, East Asian Pop Culture: Analysing the Korean Wave, 2008. Hong Kong University Press. Retrieved May 9, 2021, from http://www.jstor.org/stable/j.ctt1xwb6n.

[4] D. Shim, Hybridity and the rise of Korean popular culture in Asia. Media, Culture \& Society, 28(1), 2006, pp. 25-44. DOI: $10.1177 / 0163443706059278(2006)$.

[5] Y. Cho, H. Zhu, Interpreting the television format phenomenon between South Korea and China through inter-Asian frameworks. International Journal of Communication, vol 11, 2017, pp.233223491.

[6] M. Niedenführ, The Tug-of-War between Regulatory Interventions and Market Demands in the Chinese Television Industry. The Political Economy of Communication, 1(1) ,2013.

[7] J. JOO, Transnationalization of Korean popular culture and the rise of "pop nationalism" in Korea. The Journal of Popular Culture, 2011, 44(3), pp. 491-491. doi:10.1111/j.15405931.2011.00845.x.

[8] S. Lee, The Structure of the Appeal of Korean Wave Texts. Korea Observer, vol 43, 2012, pp. 449.

[9] D. Yang, A. S. Tedesco, The introduction of South KOREAN reality shows in the Chinese market. In The introduction of South Korean reality shows in the Chinese market, 2015, pp. 26-27. Philadelphia, PA: Drexel University.

[10] H. K. Chung, K. R. Chung, H. J. Kim, Understanding Korean food culture from Korean paintings, in: Journal of Ethnic Foods,Korean Food Research Institute, vol 3, 2016, pp.42-50. DOI: https://doi. org/10.1016/j.jef. 2016.01.002.

[11] S.H. Kim, M.S. Kim, M.S. Lee, et al, Korean diet: Characteristics and historical background, in: Journal of Ethnic Foods, Korean Food Research 
Institute, vol 3, 2016, pp.2631.DOI:https://doi.org/10. 1016/j.jef.2016.03.002.

[12] R. G. Tian, K. Tian, Z. Dandan, C. H. Wang, FOOD CULTURE IN CHINA: FROM SOCIAL POLITICAL PERSPECTIVES, in: Journal of the Humanities and Social Sciences(JHSS), vol 22, 2018, pp.345.

https://doi.org/10.3176/tr.2018.4.

[13] Y. Xiao, J. Hu, The inheritance and spreading of Confucianism in modern China and South Korea, in: 2019 5th International Conference on Social Science and Higher Education,Atlantis Press(ICSSHE 19),vol.336,2019, pp.1061-1064.

[14] C. Y. Lee, Korean culture and its influence on business practice in South Korea,in: The Journal of International Management Studies(JIMS), vol 7, 2012, pp.184-191.
[15] X. Zeng, On the Influence of Chinese Traditional Etiquette Culture on Tourism Management, Proceedings of the 2020 5th International Conference on Modern Management and Education Technology (MMET),Atlantis Press, 2020,pp.43-46.

[16] D. Sethi, Business Etiquette in China: Analysis Based on Literature Review,2016.

[17] A. K. K. Chan, L. Denton, A. S. L. Tsang, The art of gift giving in China, in: G. C. Fisher, Business Horizons, vol 46, 2003, pp.47-52. DOI:https://doi.org//10.1016/S00076813(03)00051 $-\mathrm{X}$.

[18] W. Zeng, C. Sparks, Localization as negotiation: Producing a Korean format in contemporary China, in:P. losifidis International Journal of Digital Television, $\quad$ vol8, 2017,pp.81-98. DOI:https://doi.org/10.1386/jdtv.8.1.81_1. 